\title{
Título da Página electrónica: Attac France
}

Endereço: www.france.attac.org

Vanda Pacheco

\section{(2) OpenEdition}

\section{Journals}

Edição electrónica

URL: http://journals.openedition.org/rccs/1004

DOI: $10.4000 /$ rccs. 1004

ISSN: 2182-7435

\section{Editora}

Centro de Estudos Sociais da Universidade de Coimbra

Edição impressa

Data de publição: 1 outubro 2005

Paginação: 220-221

ISSN: 0254-1106

Refêrencia eletrónica

Vanda Pacheco, «Título da Página electrónica: Attac France », Revista Crítica de Ciências Sociais

[Online], 72 | 2005, posto online no dia 01 outubro 2012, consultado o 22 setembro 2020. URL : http:// journals.openedition.org/rccs/1004; DOI : https://doi.org/10.4000/rccs.1004 


\section{Espaço Virtual}

\section{Título da Página electrónica: Directory of social movements Endereço: www.social-movements.org}

O directório de movimentos sociais é um banco de dados de âmbito mundial que reúne e combina dois tipos de informações: por um lado, ficheiros que listam as organizações e redes de movimentos sociais, fornecendo uma breve caracterização dos seus objectivos, exigências, estratégias, acções de luta e contactos; por outro, um vasto leque de artigos que contextualiza estes mesmos movimentos, analisando as suas dinâmicas e impactos produzidos.

As informações listadas nesta página são apoiadas por uma estrutura intercontinental de centros de pesquisa (América Latina - OSAL/CLACSO; Ásia - ARENA; África - Arab and African Research Centre; América do Norte - Alternatives; Europa -
CETRI), o que fornece maior credibilidade às informações.

Além de ser uma página apelativa e de rápido acesso, a navegação é bastante acessível, pois conta também com um motor de busca que facilita a pesquisa. Esta, apesar de se poder executar directamente a partir dos ficheiros das organizações ou dos artigos, permite, com o motor de busca, o cruzamento de informações como o local (país ou região) e o tema, obtendo-se assim uma perspectiva alargada dos Movimentos Sociais contemplando as suas dimensões geográfica, histórica, política e sociológica.

Disponível em inglês, francês e castelhano, esta é sem dúvida uma das páginas de maior utilidade.

\section{Título da Página electrónica: Protest Net Endereço: www.protest.net}

Esta página consiste numa listagem de movimentos sociais à escala mundial, onde estão registados inúmeros sites e com informação constantemente actualizada sobre eventos a realizar. Estes eventos estão organizados por data, cidade, região e tema e podem ser de vários tipos: beneficência, conferências/fóruns, encontros, protestos, acontecimentos especiais e outros.

Os mentores desta página descrevem-se como um grupo de activistas que trabalham para criar os seus próprios Media, divulgando e promovendo aqui as suas actividades políticas, eventos realizados e a realizar.
As áreas temáticas contempladas nesta página são: direitos dos Animais; Crianças e Educação; Direitos Civis; Pena de Morte; Drogas; Eleições e Democracia; Ambiente; Fascismo e Ideologia de Direita; Feminismo; Alimentação e Agricultura; Globalização e Imperialismo; Direitos Humanos; Imigração e Refugiados; Iraque; Trabalho e Sindicalismo; Paz; Media; Pobreza; Racismo; Religião; Sexualidade; Terceiro Mundo.

Além de permitir e incitar mesmo à inscrição de eventos on-line, tornando-se assim uma página constantemente actualizada, este site conta ainda com um interessante conjunto de artigos que incentivam ao acti- 
vismo, além de um observatório de imprensa com artigos favoráveis e desfavoráveis à natureza e objectivos do próprio site. (A título de curiosidade, este site já foi acusado de incitar à desobediência civil e organizar actos de violência, assim como de se tornar numa força democratizante muito bem capitalizada pelos activistas que verdadeiramente almejam transformar o mundo).

É uma página de rápido acesso e fácil navegação, apenas pecando pela não funcionalidade do seu motor de busca interno e pela não selectividade dos dados colocados on-line, o que por vezes se traduz num excesso de informação.

\section{Título da Página electrónica: Social Movements International Secretariat Endereço: www.movsoc.org}

Esta página, disponível em inglês e castelhano, foi criada por um conjunto de activistas de movimentos sociais, que em comum dizer ter a luta contra a "globalização neoliberal, a guerra, o racismo, o sistema de castas, o fanatismo religioso, a pobreza , o patriarcado e todas as formas de discriminação e exclusão económica, étnica, social, política, cultural, sexual e de género".

Destacam-se os documentos produzidos no âmbito dos cinco Fóruns Sociais Mundiais (FSM) já realizados, tais como as Declarações anuais, que constam em inglês, francês, português e castelhano e outros documentos de trabalho que aí estiveram em discussão.

Disponibilizam-se ainda nesta página cerca de uma centena de artigos e textos académicos produzidos por conferencistas/activistas/cientistas sociais, nos idiomas originais em que foram produzidos, além da divulgação de Encontros e Campanhas e relatórios daí emanados.

Há ainda um capítulo dedicado às questões sindicais e um conjunto de boletins informativos de periodicidade irregular, de que se espera uma rápida actualização.

Por último, conta com um considerável conjunto de ligações a todos os movimentos sociais de alguma forma ligados à iniciativa dos FSM.

Com um visual agradável e uma navegação fácil, esta é uma página de interesse tanto para activistas como académicos.

\section{Título da Página electrónica: Attac France Endereço: www.france.attac.org}

\begin{abstract}
A ATTAC (Associação para Taxação de Transacções Financeiras para Ajuda aos Cidadãos) foi fundada em França em 1998, com o objectivo de lutar pela implementação da taxa Tobin, um instrumento de regulação dos mercados cambiais, promovendo desde então um combate cerrado ao poder que a esfera financeira exerce sobre todos os aspectos da vida política, social e cultural ao nível mundial.
\end{abstract}

Descrevendo-se como um "movimento de educação popular”, esta associação produz relatórios, organiza conferências e reuniões públicas e participa em manifestações.

Em finais de 2004, já se encontrava presente em cerca de cinquenta países.

A Attac France conta com cerca de 30 mil membros e 215 comités. Na sua página electrónica, que aliás é constantemente actualizada, é possível encontrar os estatutos da associação, respectivos corpos 
sociais, o programa de acção, a descrição das comissões e grupos de trabalho, assim como dos comités locais.

Disponibilizam ainda para os eventuais interessados um serviço que lhes permite receber directamente no seus endereços electrónicos, comunicados, declarações e outras informações produzidas no seu âmbito, apesar destas constarem obviamente na página.

Conta também com um motor de pesquisa interno que permite uma pesquisa bastante alargada, desde pesquisa textual, temática, por dossiês, por fontes, folhetos/catálogos, fotos e imagens, ou ainda um calendário onde estão elencadas as acções a encetar/ encetadas.

Para facilitar a pesquisa aos visitantes mais regulares, listam num directório de entrada os documentos mais recentes.

Vanda Pacheco
vanda@ces.uc.pt 